\title{
Implementasi dan Analisis Perangkat Pengirim Data Sensor melalui Modul A6 GSM/GPRS berbasis Microcontroller
}

\author{
I Gede Eka Wiantara Putra, I Ketut Putu Suniantara, I Nyoman Satya Kumara \\ Program Studi Sistem Komputer, Program Studi Sistem Informasi, Jurusan Teknik Elektro \\ STMIK STIKOM Bali, Fakultas Teknik Universitas Udayana \\ Bali, Indonesia \\ wiantara@stikom-bali.ac.id, suniantara@stikom-bali.ac.id, satya.kumara@unud.ac.id
}

\begin{abstract}
Abstrak-Pengiriman data sensor dari suatu peralatan akuisisi umumnya dilakukan melalui jaringan lokal, baik menggunakan media kabel maupun wireless. Metode ini memiliki kelemahan pada rentang jarak pengiriman data antara peralatan pengirim dengan penerima. Mengatasi permasalahan tersebut, pada makalah ini disampaikan implementasi perangkat pengirim data sensor pada peralatan akuisisi ke web server melalui jaringan GPRS menggunakan modul A6 GSM/GPRS berbasis microcontroller. Melalui modul ini, data dari rangkaian sensor diterima oleh microcontroller dan diteruskan ke modul A6 untuk di-post ke web server. Hasil analisis terhadap implementasi perangkat ini menunjukkan bahwa dibutuhkan waktu rata-rata 10.2 detik untuk setiap pengiriman data ke web server. Sedangkan daya listrik ratarata yang dibutuhkan saat data dikirimkan adalah 947.56 mWatt. Hasil penelitian ini selanjutnya akan dijadikan dasar implementasi pengiriman dan pemetaan data intensitas cahaya matahari di Provinsi Bali.
\end{abstract}

Kata kunci: modul A6 GSM/GPRS, IoT, Wireless Sensor Network, Microcontroller

\section{PENDAHULUAN}

Data yang dihasilkan suatu perangkat sensor umumnya dikirimkan melalui jaringan lokal, baik menggunakan kabel maupun nirkabel. Penggunaan kabel pada jaringan lokal memiliki keunggulan dalam hal kecepatan pengiriman data, namun dibatasi pada panjang kabel dan penerapannya di suatu area pengukuran. Dengan demikian, maka area pengukuran jarak jauh akan terkendala pada sisi besarnya biaya pembangunan infrastruktur. Di sisi lain, jaringan nirkabel menjadi solusi terhadap penerapan pengiriman data tanpa dibatasi oleh jarak area pengukuran, namun kecepatan pengiriman data tidak lebih baik daripada menggunakan kabel. Meskipun demikian, solusi tersebut memiliki banyak keunggulan lainnya, sehingga dapat diterapkan pada area pengukuran jarak jauh secara lebih efektif dan efisien [1].
Pengiriman data sensor dari perangkat akuisisi ke web server akan membutuhkan sebuah media internet. Dalam hal ini, secara umum perangkat akuisisi akan dihubungkan ke jaringan internet melalui jaringan WiFi yang tersedia di suatu area pengukuran yang telah terhubung dengan Internet Service Provider (ISP). Namun hal ini akan menjadi kendala ketika tidak tersedianya jaringan $\mathrm{WiFi}$ di area pengukuran. Berdasarkan permasalahan tersebut, pada makalah ini disampaikan implementasi perangkat pengirim data sensor melalui jaringan GPRS menggunakan modul A6 berbasis microcontroller untuk di-post ke suatu web server. Metode ini menjadi solusi alternatif, di mana selain mencakup area yang lebih luas, keunggulan penggunaan jaringan GPRS pada perangkat pengirim data adalah dapat dipindahkan ke lokasi pengukuran lainnya tanpa harus melakukan pengaturan ulang terhadap perangkat tersebut.

Penelitian terkait konektivitas dan pengiriman data melalui jaringan GPRS telah banyak dilakukan, namun secara umum sebagaimana penelitian oleh Zaghloul \& Mohamed Saad [2], menggunakan modul SIM900 dan oleh Hongzhou et al., [3], menggunakan modul ZigBee yang lebih mahal. Terkait dengan hasil implementasi dan analisis dari penelitian ini yang selanjutnya akan diterapkan pada perangkat sensor di dalam sistem pengikut matahari secara lebih efektif dan berbiaya rendah, bertujuan untuk memetakan intensitas cahaya matahari di Provinsi Bali sebagai acuan pembangunan Pembangkit Listrik Tenaga Surya (PLTS). Dengan demikian, maka diharapkan tidak menutup kemungkinan bagi masyarakat umum untuk membangun sistem ini dengan lebih mudah.

\section{METODE}

Penelitian ini diawali dengan mengumpulkan referensi terkait metode pengiriman data melalui jaringan GPRS yaitu menggunakan sebuah modul berbasis microcontroller. Dalam penelitian ini, digunakan sebuah modul A6 GSM/GPRS dengan perintah-AT (AT-command [4]) yang dihubungkan dengan microcontroller Arduino Pro-Mini untuk 
menghasilkan perangkat berdimensi kecil. Metode pengiriman data dan skema rangkaian perangkat pengirim data ini ditunjukkan masing-masing seperti pada Gambar 1 dan Gambar 2.

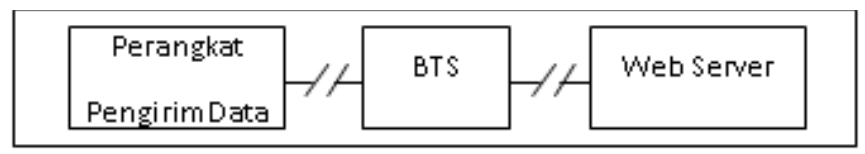

Gambar 1 Metode pengiriman data

Pada Gambar 1, data yang akan dikirimkan bersumber dari perangkat pengirim data sebagaimana skema yang ditunjukkan pada Gambar 2. Selanjutnya, perangkat tersebut dihubungkan ke jaringan internet melalui konektivitas jaringan GPRS. Jaringan GPRS disediakan oleh berbagai layanan seluler di Indonesia melalui Base Transceiver Station (BTS). Dengan demikian, maka terhubungnya perangkat dengan jaringan internet akan memungkinkan adanya proses pengiriman data ke sebuah web server.

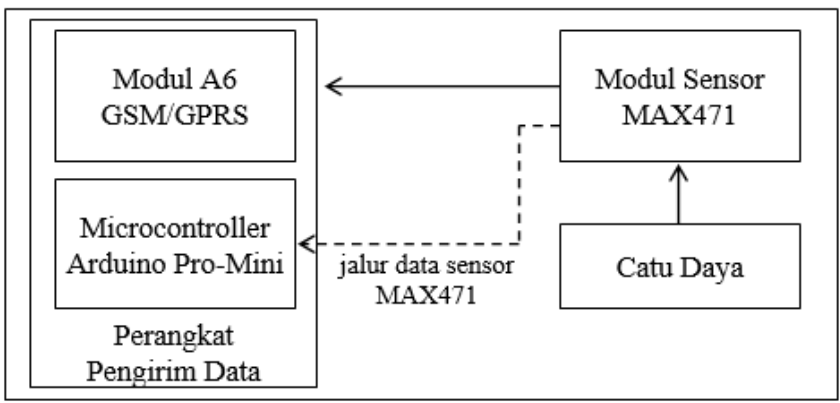

Gambar 2 Skema rangkaian perangkat pengirim data.

Perangkat pengirim data pada Gambar 2 tersusun atas dua komponen, yaitu microcontroller dan modul GPRS. Komunikasi kedua komponen tersebut dilakukan secara serial melalui pin Tx dan Rx. Dalam hal ini, microcontroller diprogram untuk memberikan perintah kepada atau menerima respon dari modul GPRS tersebut.

\section{A. Konektivitas GPRS}

Sebelum data dikirimkan, untuk menghubungkan modul A6 ke jaringan GPRS, dibutuhkan beberapa tahap seperti bagan pada Gambar 3 .

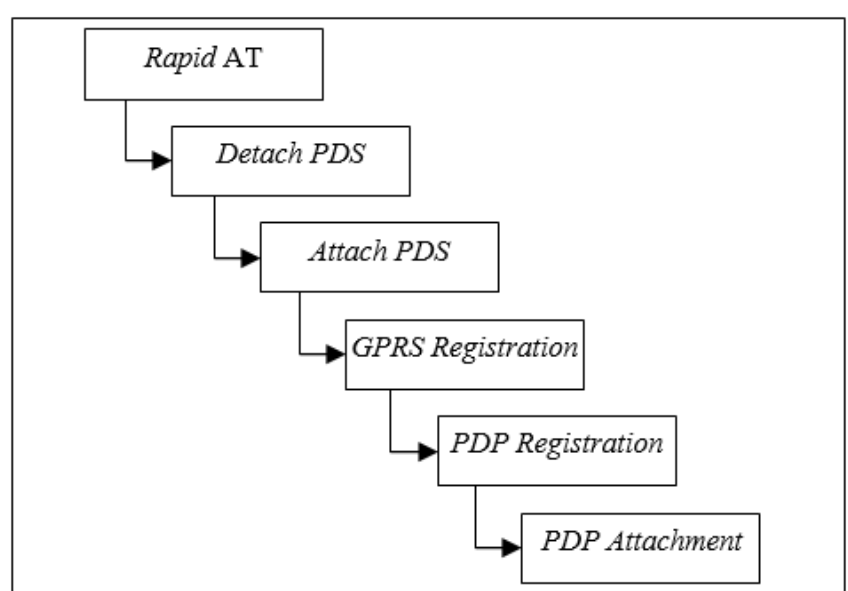

Gambar 3 Bagan tahapan konektivitas GPRS

\section{1) Rapid AT}

Tahap ini merupakan awal komunikasi antara modul A6 dengan microcontroller. Dengan memberikan perintah AT melalui serial monitor, maka modul A6 akan merespon OK. Bila modul tidak merespon, maka dibutuhkan pengulangan perintah AT secara berkala dan stabil. Tahap ini merupakan bagian yang penting sebagai indikator bahwa modul A6 telah siap menerima perintah selanjutnya.

\section{2) Detach Packet Domain Service (PDS)}

Tahap ini merupakan pengkondisian layanan kartu SIM agar tidak terhubung (detach) dengan PDS. Hal ini diperlukan untuk mengkondisikan layanan kartu SIM untuk perintah selanjutnya dan mengurangi kemungkinan detach secara tibatiba. Untuk melakukan detach, modul A6 diberikan perintah $\mathrm{AT}+\mathrm{CGATT}=0$, yang mana 0 berarti detach dan akan direspon OK bila berhasil atau +CME ERROR bila gagal.

3) Attach Packet Domain Service (PDS)

Tahap ini merupakan bagian untuk menghubungkan (attach) layanan kartu SIM dengan PDS. Perintah yang diberikan adalah $\mathrm{AT}+\mathrm{CGATT}=1$, yang mana 1 berarti attach dan akan direspon OK bila berhasil atau +CME ERROR bila gagal.

\section{4) GPRS Registration}

Tahap ini merupakan upaya pendaftaran kartu SIM untuk konektivitas GPRS pada penyedia layanan. Perintah yang diberikan adalah AT+CGREG=2, yang mana 2 berarti enable dan akan direspon +CGREG: 2,1,"<location area code $>$ ", $<$ cell ID $>$ " atau +CME ERROR bila gagal.

\section{5) Packet Data Protocol (PDP) Context Registration}

Tahap ini merupakan lanjutan tahap registrasi GPRS dengan memasukkan tipe PDP dan Access Point Name (APN) dari penyedia layanan. Perintah yang diberikan adalah AT+CGDCONT=1,"IP"," $<$ APN $>$ ", yang mana 1 merupakan identifier, dan "IP" merupakan tipe PDP, sedangkan " $<$ APN $>$ " merupakan Access Point Name yang disediakan oleh penyedia layanan seluler. Selanjutnya modul akan 
merespon +CGDCONT:1,"IP"," $<$ APN $>$ ", $, 0,0$ atau +CME ERROR bila gagal.

\section{6) PDP Attachment}

Setelah registrasi berhasil, selanjutnya modul A6 diberikan perintah $\mathrm{AT}+\mathrm{CGACT}=1,1$ untuk aktivasi PDP Context dan modul akan merespon +CGACT: $(1,1)$ atau +CME ERROR bila gagal.

Bila salah satu perintah dari enam tahap tersebut mengalami kegagalan (dengan respon: +CME ERROR), maka kegagalan respon akan terjadi pula pada tahap selanjutnya. Dalam hal ini, maka proses tahapan konektivitas harus diulangi dari awal.

\section{B. Pengiriman Data}

Enam tahap pada sub bab 2.1 merupakan awal konektivitas internet melalui jaringan GPRS, sedangkan untuk memulai pengiriman data dibutuhkan langkah-langkah seperti pada Gambar 4.

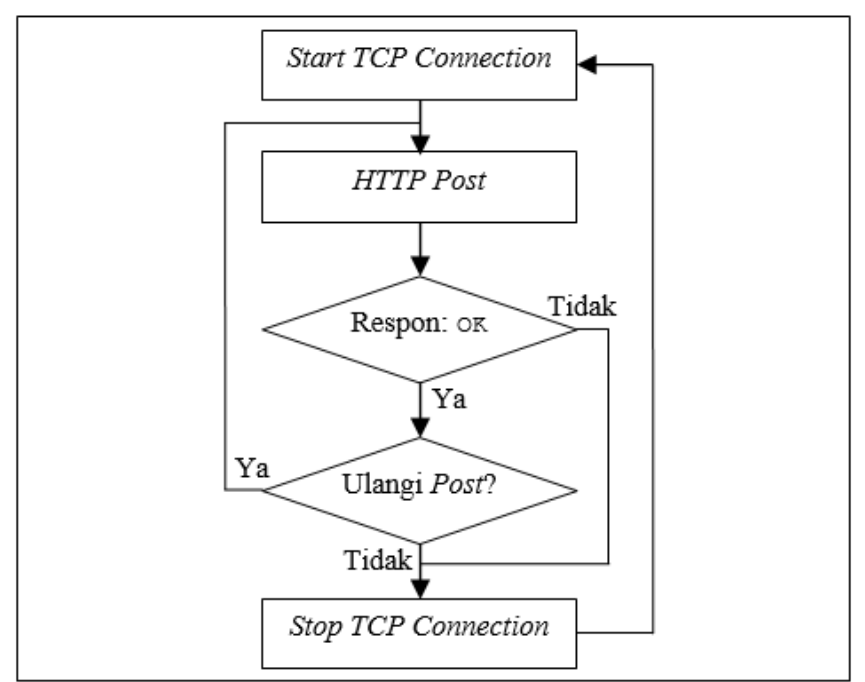

Gambar 4 Langkah pengiriman data ke web server

\section{1) Start TCP Connection}

Tahap ini merupakan upaya menghubungkan perangkat dengan alamat web server melalui TCP. Perintah yang digunakan adalah AT+CIPSTART="TCP", $<$ IPAddress $>$ ",Port dan modul akan merespon CONNECT OK atau +CME ERROR bila gagal.

\section{2) HTTP Post Data}

Untuk mengirimkan data ke web server, diperlukan metode Post yang dituliskan setelah modul merespon > melalui perintah AT+CIPSEND. Perintah Post membutuhkan format yang harus sesuai dengan web server, sebagaimana ditunjukkan pada gambar 5. Setelah menerima respon dari modul A6, perintah Post dapat diulangi kembali sesuai dengan kebutuhan. Di sisi lain, bila perintah Post tersebut gagal, maka harus dilakukan pemutusan koneksi TCP melalui perintah AT+CIPCLOSE sebelum memulai koneksi yang baru.

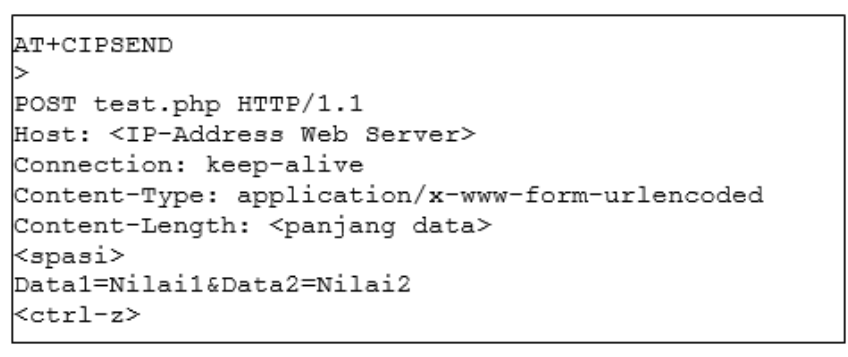

\section{Gambar 5 Format HTTP Post}

Melalui serial monitor pada Arduino IDE, <ctrl-z> dituliskan dalam bentuk bilangan hexadecimal (0x1A) sebagai perintah mengirimkan data Post. Bila berhasil, modul akan merespon $\mathrm{OK}$ atau $+\mathrm{CME}$ ERROR bila gagal.

\section{Kebutuhan Daya Listrik}

Selain konektivitas dan metode pengiriman data melalui jaringan GPRS, dalam penelitian ini ditambahkan analisis terhadap kebutuhan daya listrik pada perangkat pengirim data sebagai acuan perancangan dan implementasi perangkat sensor atau pengakuisisi data. Teknik pengukuran daya listrik ini melibatkan sebuah modul sensor tegangan dan arus MAX471 sebagaimana ditunjukkan pada Gambar 2. Modul ini mampu memberikan nilai tegangan dan arus dalam 10 bit melalui pin ADC pada microcontroller [5].

Perhitungan nilai tegangan (V) dilakukan dengan memasukkan persamaan (1), di mana secara hardware, modul ini dirancang menggunakan sistem pembagi tegangan dengan perbandingan 1:5. Hal ini berarti bahwa tegangan maksimal yang mampu diukur adalah 5 kali tegangan kerja microcontroller. Dengan demikian, untuk microcontroller dengan tegangan kerja 5 Volt akan mampu mengukur tegangan maksimal 25 Volt. Sedangkan perhitungan nilai arus (I) dihitung dengan persamaan (2). Sebagaimana hukum ohm pada persamaan (3), perhitungan daya listrik (P) merupakan tegangan (V) dikalikan dengan arus (I).

$$
\begin{gathered}
V=\text { nilai bit } A D C *(\text { tegangan micro } / 1024) * 5 \\
I=\text { nilai bit } A D C *(\text { tegangan micro } / 1024) \\
P=V * I
\end{gathered}
$$

\section{HASIL DAN PEMBAHASAN}

\section{A. Implementasi dan Pengujian Hardware}

Implementasi perangkat pengirim data sensor menggunakan sebuah modul A6 GSM/GPRS dan sebuah microcontroller Arduino Pro-Mini yang telah disesuaikan dengan rancangan rangkaian sebagaimana ditunjukkan pada Gambar 2. Hasil pengimplementasian tersebut ditunjukkan seperti pada Gambar 6. Pin Tx pada modul A6 dihubungkan dengan Pin 2 sebagai Pin Rx, sedangkan Pin Rx pada modul dihubungkan dengan Pin 3 sebagai Pin Tx. Catu daya untuk perangkat ini adalah 5 Volt.

Penyelenggara : Jurusan Pendidikan Teknik Informatika, Fakultas Teknik dan Kejuruan, 
Pengujian awal dilakukan dengan membuat sebuah panggilan ke nomor kartu SIM yang terpasang pada perangkat menggunakan perangkat telepon lainnya. Bila panggilan tersebut memunculkan nada sambung, maka kartu SIM dalam perangkat tersebut telah aktif, dan perangkat siap dikendalikan. Di sisi lain, dalam menerima perintah atau panggilan, modul A6 akan membutuhkan waktu persiapan dengan kisaran 5 detik hingga 10 detik. Hal ini dapat dilihat melalui indikator nyala LED biru pada modul A6.

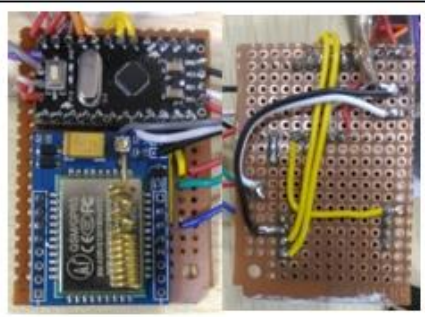

Gambar 6 Rangkaian perangkat pengirim data.

\section{B. Implementasi dan Pengujian Software}

Software pada perangkat diimplementasikan menggunakan Arduino IDE dan disesuaikan dengan perintah AT untuk modul A6. Baris pertama dan ke dua pada Gambar 6 menunjukkan upaya penyesuaian komunikasi serial antara Arduino Pro-Mini dengan modul A6. Dalam hal ini, perintah dan respon pada modul A6 dapat ditampilkan melalui serial monitor dengan baud rate 9600 .

Hasil pengujian konektivitas GPRS melalui modul A6 ini menunjukkan adanya kebutuhan delay yang tepat untuk setiap perintah yang diberikan. Kebutuhan delay ini disebabkan oleh perbedaan waktu respon yang diterima oleh modul A6 dari penyedia layanan seluler untuk masing-masing perintah.

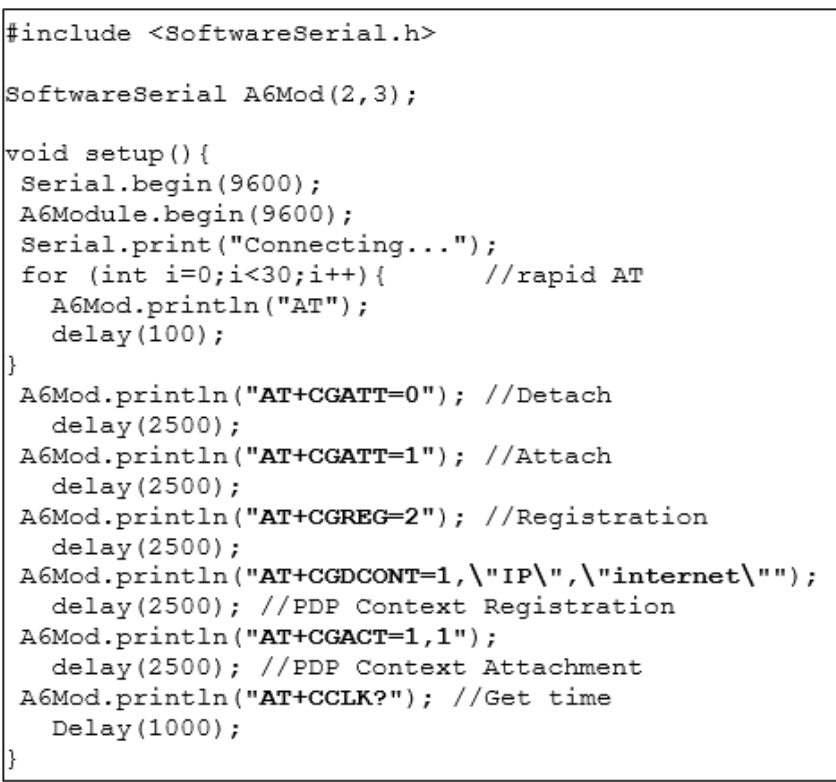

Gambar 7 Implementasi tahapan konektivitas GPRS
Setelah konektivitas GPRS berhasil, proses selanjutnya adalah pengiriman data ke web server menggunakan metode HTTP Post. Implementasi perintah AT melalui Arduino IDE ditunjukkan pada Gambar 7. void cipStart() pada Gambar 7 merupakan implementasi perintah konektivitas modul A6 ke IP-address tujuan. Konektivitas ini akan membutuhkan waktu yang cukup, sehingga diperlukan pembacaan respon CONNECT OK dari modul A6 sebelum dilanjutkan ke perintah pengiriman data. Sedangkan bagian void cipSend() merupakan implementasi perintah mengirimkan data ke web server. Dalam hal ini, modul A6 akan menerima data HTTP dari web server yang mengindikasikan status pengiriman data. Hasil tersebut ditunjukkan pada Gambar 8 dengan menampilkan status pengiriman data. Hal ini menjadi indikator keberhasilan pengiriman data oleh modul A6, dimana bagian A mengindikasikan keberhasilan pengiriman, dan bagian B mengindikasikan kegagalannya. Menyikapi kegagalan pengiriman data, dibutuhkan perintah AT+CIPCLOSE dan mengulangi bagian void cipStart().

Pengendalian ketika proses penutupan koneksi dengan perintah AT+CIPCLOSE tidak memperoleh respon yang sesuai, maka dilakukan restart modul secara hardware melalui perintah AT+CPOF. Dalam hal ini, modul A6 akan dimatikan dan dinyalakan kembali. Proses ini membutuhkan waktu 10 detik sebelum perintah konektivitas GPRS kembali dilakukan.

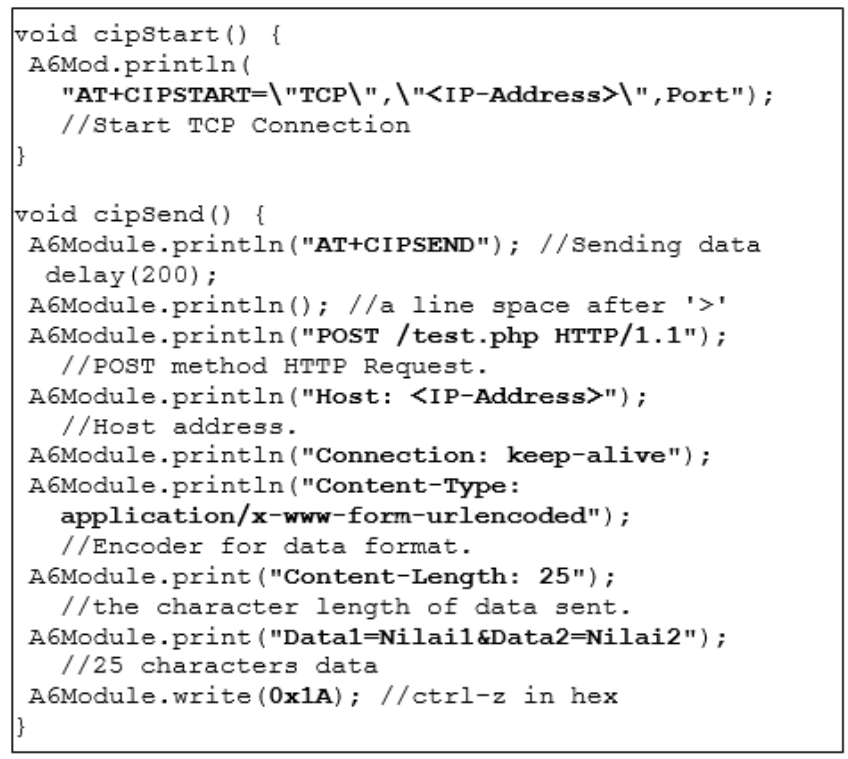

Gambar 8 Implementasi tahapan pengiriman data

\section{Analisis Waktu Pengiriman Data}

Akumulasi delay yang diimplementasikan pada program mulai dari menyalakan modul hingga pengiriman data pertama adalah 22.7 detik. Hal ini berarti bahwa apabila sistem berkerja secara normal, maka dibutuhkan waktu 22.7 detik untuk memulai pengiriman data. Dalam hal kegagalan

Penyelenggara : Jurusan Pendidikan Teknik Informatika, Fakultas Teknik dan Kejuruan,

Universitas Pendidikan Ganesha, 


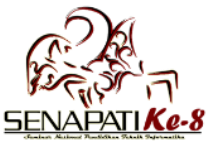

konektivitas dan jenis kesalahan lainnya, maka ditambahkan langkah restart perangkat dengan kebutuhan waktu tambahan 10 detik. Berdasarkan 40 data waktu sampel yang terbagi menjadi 4 bagian di mana masing-masing berdurasi 2.5 menit, waktu yang dibutuhkan untuk mengirimkan setiap data secara berulang berkisar antara 10 detik hingga 12 detik dengan waktu rata-rata 10.2 detik.

\section{Analisis Kebutuhan Daya Listrik}

Bersamaan dengan analisis waktu pengiriman data, menggunakan jumlah sampel tersebut menghasilkan kebutuhan daya listrik yang berkisar antara 859.78 mWatt hingga $1070.50 \mathrm{mWatt}$ dengan rata-rata $947.56 \mathrm{mWatt}$. Sedangkan kebutuhan daya listrik yang dimulai dari menyalakan perangkat hingga perintah koneksi TCP berkisar antara $679.45 \mathrm{mWatt}$ hingga $709.95 \mathrm{mWatt}$ dengan rata-rata 699.32 mWatt. Hasil analisis tersebut diperoleh melalui perhitungan nilai pengukuran daya listrik pada sampel tertentu. Hal ini diperlihatkan pada Gambar 9.

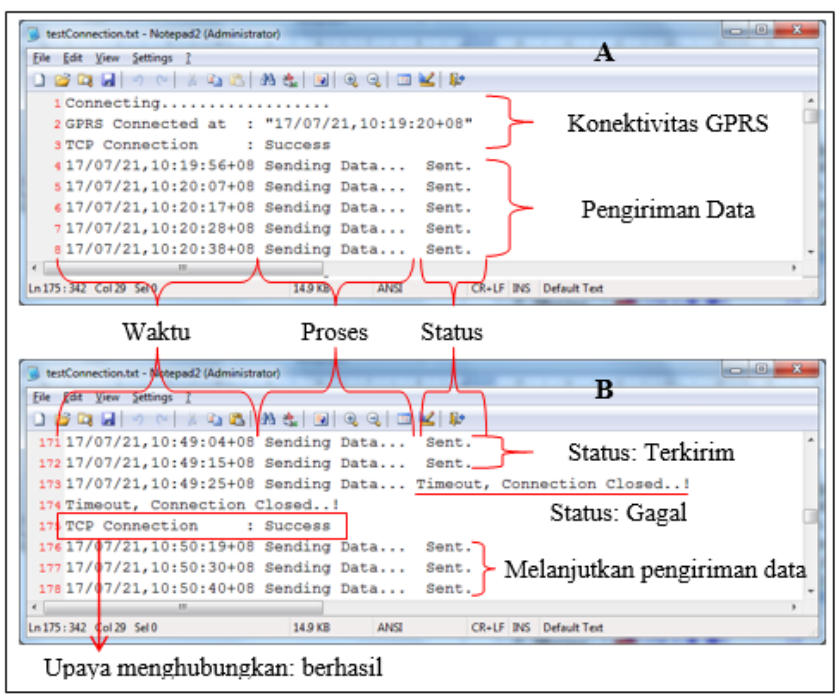

Gambar 9 Hasil pengujian pengiriman data.

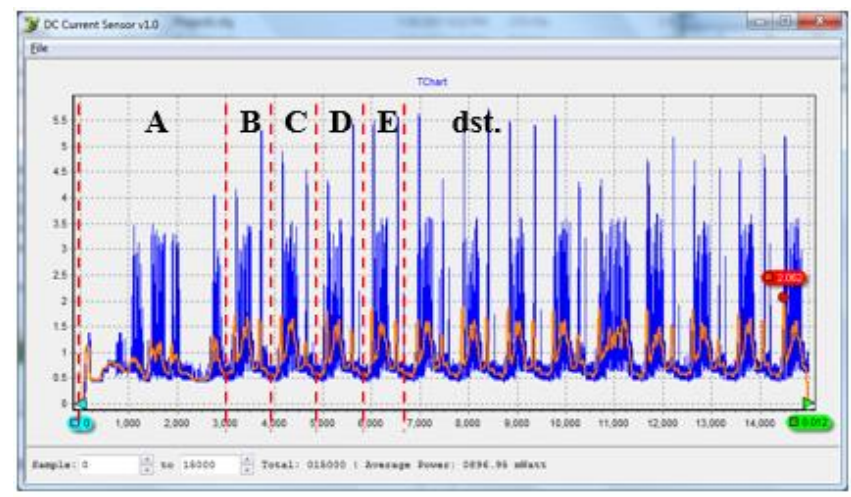

Gambar 10 Hasil plotting data sampel daya listrik
ISSN 2087-2658

Prosiding Seminar Nasional Pendidikan Teknik Informatika

(SENAPATI) Ke-8

Bali, 09 September 2017

Bagian A pada Gambar 9 merupakan kebutuhan daya dari awal perangkat dinyalakan hingga konektivitas TCP. Sedangkan bagian B, C, D, E, dst., merupakan tahap pengiriman data. Kebutuhan daya listrik pada pengiriman setiap data relatif stabil dengan pola seperti ditunjukkan pada Gambar 10. Pola tersebut diperjelas dengan menambahkan metode moving average sebesar 100 sampel.

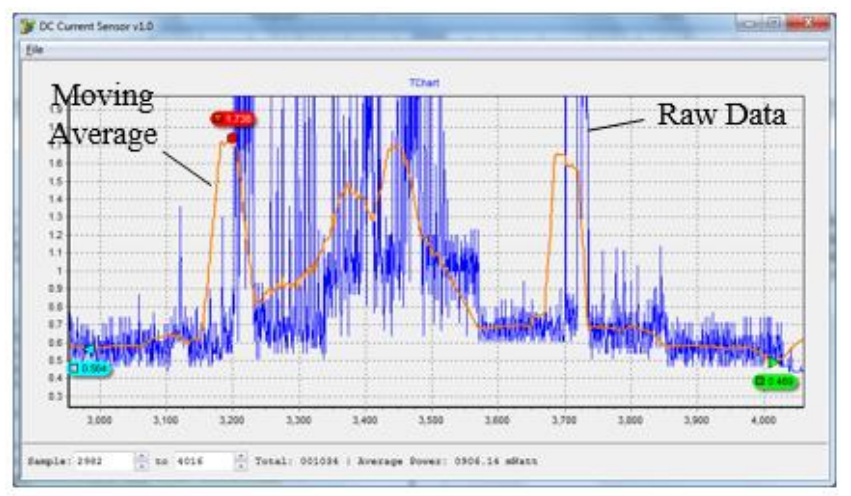

Gambar 11 Pola kebutuhan daya listrik perangkat

\section{KESIMPULAN}

Pengiriman data menggunakan jaringan GPRS dapat diimplementasikan menggunakan modul A6 GSM/GPRS berbasis Arduino Pro-Mini. Hasil pengujian terhadap waktu rata-rata yang dibutuhkan untuk mengirimkan satu data ke web server adalah 10.2 detik dengan kebutuhan daya listrik rata-rata sebesar $947.56 \mathrm{mWatt}$.

Peningkatan terhadap efektifitas waktu pengiriman data dapat dilakukan dengan mengurangi waktu delay pada setiap tahapan perintah. Namun demikian, kestabilan konektivitas modul A6 ke jaringan GPRS akan berkurang. Di sisi lain, kemampuan perangkat pengirim data ini selanjutnya dapat diimplementasikan pada perangkat pengakuisisi data jarak jauh namun masih dalam jangkauan sinyal BTS.

\section{UCAPAN TERIMAKASIH}

Penelitian ini didukung dan dibiayai oleh Kementerian Riset, Teknologi, dan Pendidikan Tinggi pada Program Insentif Riset Sistem Inovasi Nasional (Insinas) Gelombang II, 2017, Nomor: 25/INS-2/PPK/E/E4/2017

\section{DAFTAR PUSTAKA}

[1] Xiaorong, C., Zhan, S., Zhenhua, G. "Research on remote data acquisition system based on GPRS." Electronic Measurement and Instruments, 2007. ICEMI'07. 8th International Conference on 2007 Aug 16 (pp. 2-20). IEEE.

[2] Zaghloul, Mohamed Saad. "GSM-GPRS Arduino Shield (GS-001) with SIM900 chip module in wireless data transmission system for data acquisition and control of power induction furnace." International Journal of Scientific \& Engineering Research 5, no. 4 (2014): 776. 
[3] Yu, Hongzhou, Lu Liu. "Remote health monitoring system using zigbee network and gprs transmission technology" Computational Intelligence and Design (ISCID), 2011 Fourth International Symposium on. Vol. 1. IEEE.

[4] Ai-Thinker Inc, A6 GSM/GPRS Module, V1.01.
[5] Park, C., Chou, P.H. "Ambimax: Autonomous energy harvesting platform for multi-supply wireless sensor nodes." Sensor and Ad Hoc Communication and Networks, 2006. SECON'06. 2006 3rd Annual IEEE Communication Society on. Vol. 1. IEEE. 